\title{
The NBC islands gag
}

In April, the Wingti Government imposed an unprecedented gag on the National Broadcasting Commission reporting an Islands region premiers summit expected to debate possible secession from PNG.

\section{By NEVILLE TOGAREWA}

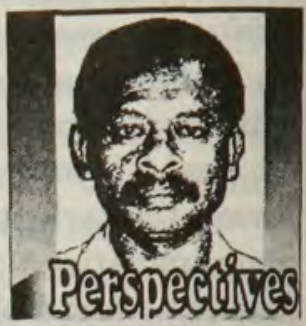

The order by Papua New Guinea's Information and Communication Minister and Acting Attorney-General Martin Thompson in April, banning National Broadcasting Commission from reporting the New Guinea Islands leaders' talks on secession, was rash, stupid, and at worst dangerous.

Stupid because it served no purpose at all except to leave egg on the Minister's face in particular, and the Wingti Government generally; rash because it appeared that Thompson - a lawyer by profession - did not consider all the circumstances and possible implications before giving his directive; and dangerous because the order violated freedom of expression, one of the most cherished rights in any democracy such as ours.

If I were NBC chairman Sir Alkan Tololo, I would have defied the order. I would have been sacked, but so what! I'd have made my point, and felt a lot happier having made it.

Mr Thompson's action cannot be taken lightly. It happened, and it will no doubt happen again if we, the public, allow it to happen. People like Sir Alkan, who head mass media organisations whether public or private, cannot by either their action or inaction be seen to be a party to decisions or actions which prevent or restrict the right to freedom of expression enshrined in our constitution.

The issue at stake is not provincial government reforms and/or secession. It is the peoples' constitutionally guaranteed right to freedom of expression (or freedom of the press and other mass communications media).The facts are simple, as stated by a notice titled 'Commission to Refrain from Broadcasting all Matters Arising from New Guinea Islands Secession Summit (in) Kimbe' to Sir Alkan from Thompson. It states: 'Pursuant to my powers under Section 7:3 (a) and (b) of the Broadcasting Act, Chapter No 149 , I am now directing you to refrain from broadcasting any matter arising out of, or in connection with, the NGI leaders summit (being) held in Kimbe.

'Let me remind the commission that whilst it is our duty to provide a 


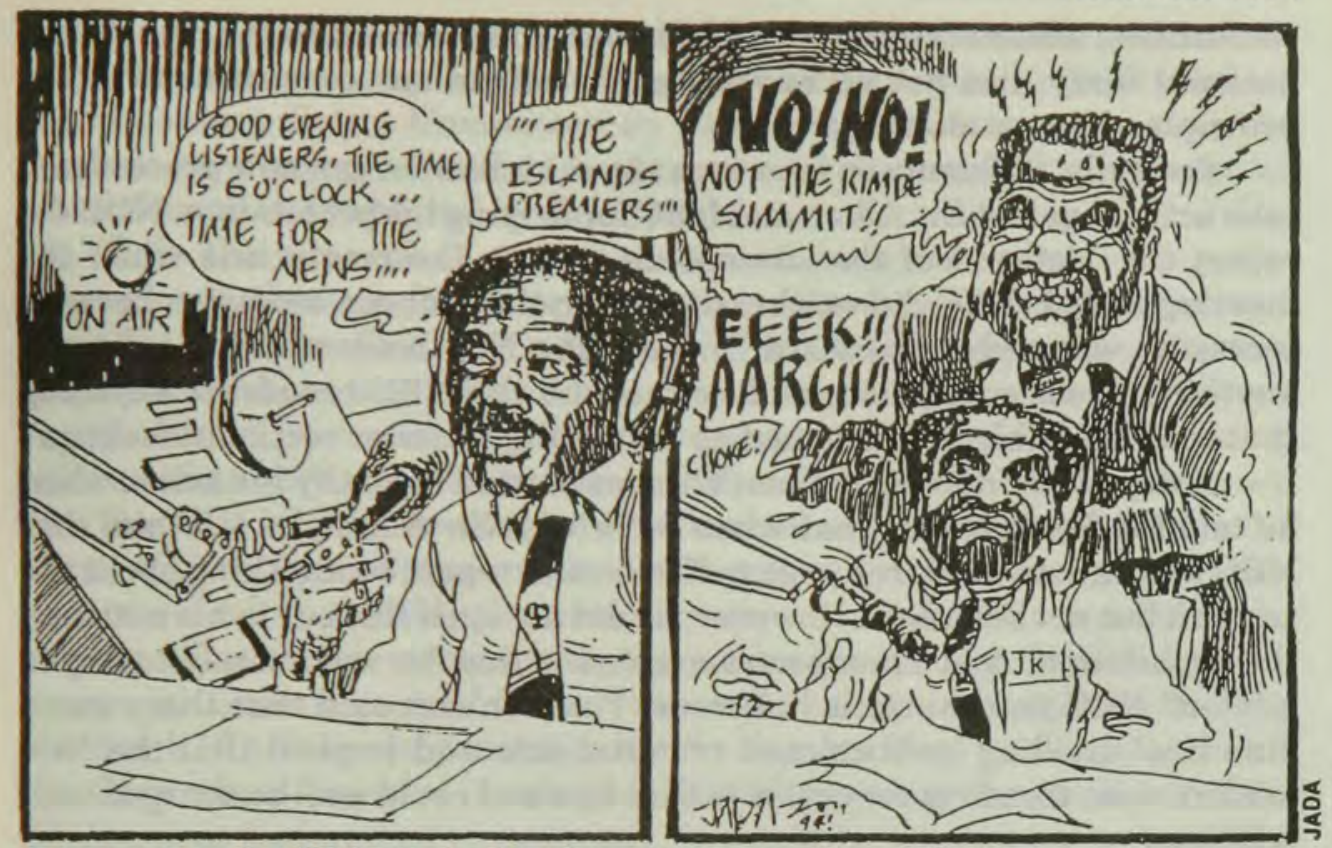

A cartoon on the NBC gag in the Times of Papua New Guinea.

balanced, objective and impartial broadcasting service, it is paramount that such services should reflect our drive for national unity and that we should take extreme care in broadcasting material that could inflame racial or sectional feelings.'

The prohibition took effect immediately and. remained in force until Thompson decided to lift it.

Section 7 (Commission and Government Policy) subsection 3 of the NBC Act provides that: 'Subject to this Act, the Minister may, from time to time, by telegram or in writing: (a) prohibit the commission from broadcasting any matter... specified in the notice; or (b) request the commission to refrain from broadcasting any such matter.'Section 6 (Functions of the commission) subsection (1) provides that the NBC has a duty to provide balanced, objective and impartial broadcasting services'. And section 6 (2) states: 'In particular, the commission shall: (c) take extreme care in broadcasting material that could inflame racial or sectional feelings.'

As can be seen, Thompson had the power to make such a prohibition. The question is whether, under the circumstances, the Minister's ban is legal. I am certain that Thompson regrets his decision. His direction was for NBC to restrain from broadcasting any matter arising out of, or in connection with the summit.

Firstly, the NGI leaders did not discuss, specificially, their threat to secede. Manus Premier and NGI spokesman on political matters Stephen Pokawin said they were not deliberately 'advocating or propounding secessionism'. This was, in fact, confirmed a day later by one of the summit's 10 


\section{Pacific Journalism Review}

resolutions, which stated: '(We) affirm (our) commitment to the principle of national unity, but not at, any price. We affirm our commitment to the principle of power sharing.'

Secondly, if Thompson is serious about his ban, he can now proceed and take action against Sir Alkan and NBC for defying his prohibition. NBC did report the deferral of the summit as well as the resolutions when the meeting ended. NBC did not broadcast anything about secession because secession was never discussed. In fact, the NGI leaders did not discuss anything about succession, and neither did the NBC broadcast anything that could possibly be construed as 'inflaming racial or sectional feelings'.

A day after ordering the ban Thompson tried to justify his action when he told the Post-Courier that when he briefed Sir Alkan, he told him that NBC journalists were free to go to Kimbe and report on anything about the summit but not secession. However, he did not spell this out in his notice on the prohibition. And Thompson's argument that he was merely trying to 'protect' NBC journalists is ludicrous. The Minister said that there was a 'fine line' dividing 'politics' and criminal acts and implied that the NGI leaders were treading very close to that line and could well be charged with sedition.

It is arguable whether NGI leaders are trying to make people rebel against National Government authority, or to disobey the Government. Thompson assumes that if one or more NGI leaders are arrested by police and charged with sedition, any NBC journalist who during the course of his or her duty reports words and actions of the leader could be seen as promoting or encouraging sucession and thus be liable to be arrested as well. Put another way, assuming Manus Premier and NGI spokesman on political matters Pokawin was arrested for sedition, journalists who had reported those things he had said which led to his arrest, could be liable to be arrested.

What does the Constitution say about the people's right to freedom of expression. Section 46 (1) provides that, 'Every person has the right to freedom of expression and publication, except to the extent that the exercise of that right is required or restricted by law: (a) that imposes restrictions on public office-holders; (b) that imposes restrictions on non citizens; or (c) that complies with Section 38 (general qualifications on qualified rights)'.

Section 46 (2) states: 'In subsection (1)freedom of expression and publication includes: (a) freedom to hold opinions, to receive ideas and information and to communicate ideas and information, whether to the public generally or to a class of persons; and (b) freedom of the press and mass communications media ' It appears then that the Government, in its haste to adopt and implement provincial government reforms, has placed itself in a position from which it cannot extricate itself.

Prime Minister Paias Wingti announced in October 1992 - coincidentally in Kimbe - cabinet's decision to abolish provincial governments. However, following strong opposition, especially from provincial govern- 
ments, a bipartisan approach adopted by Parliament to get the views of the people before any changes were made. This process begun by the Bipartisan Parliamentary Select Committee on Provincial Governments, is still in progress, now being carried out by the committee's successor, the Constitutional Commission chaired by Ben Micah.

While the process of consultation and dialogue is continuing, the Government, through the Commission, has introduced two Constitutional Amendment Bills which are now before Parliament. Milne Bay Premier Jones Liosi did not want the commission to meet his Government because he argued that there was no point in listening to their views on the proposed reforms when the two Bills are already before Parliament. Liosi has a point.

The NGI leaders meeting in Kimbe resolved that they: 'Reaffirm the stance of the Islands Premiers' Council to retain the provincial government system and call on the Constitutional Commission and the National Government to allow NGI provinces to do this under the present Organic Law on Provincial Governments. ' Some years ago, people of Bougainville demanded K10 billion compensation for the damage done by Panguna mine. The Government rejected it outright. K10 billion was outrageous but if the Government had agreed to negotiate, it would be interesting to see if the problems on Bougainville today would be the same.

A similar scenario is now being played out between the Government and the NGI provinces over the proposed provincial govenment reforms. The National Govennment appears to be hellbent on pushing the reforms through. The NGI, on the other hand, have resolved to retain the provincial government system in its current form.

There is definitely a deadlock. And nothing is going to be achieved if both parties continue to maintain their respective positions. Many a time we read and hear about our leaders preaching the Melanesian virtues of consultation and consensus. This is exactly what is needed now because tomorrow may be one day too late.

Fortunately, it is not too late. But our political leaders from both sides owe it to the people to agree to sit down in the true Melanesian spirit and thrash out their differences and come up with a mututally acceptable arrangement. The argument has gone far enough and many have been caught in the crossfire. The latest victim is the people's right to freedom of expression.

口 NEVILLE TOGAREWA is a senior political reporter for Post-Courier. This article is reprinted from his Perspectives column of 11 April 1994. 